Journal of Educational Method and Technology Vol. 2 No. 3, Desember 2019

P-ISSN 2622-8459 E-ISSN 2622-8467

http://ejournal.unima.ac.id/index.php/jemtec

\title{
Writing Skills Text Report Observation Results At XI Grade Students At SMA Negeri 2 Tondano
}

\author{
R C Paath ${ }^{1}$ \\ Universitas Negeri Manado, Indonesia \\ corresponding author: ${ }^{1}$ ruthpaath@unima.ac.id
}

\begin{abstract}
The objectives to be achieved in this study are: (1) To describe the learning steps of the communicative approach in writing descriptive text of the report on the observations of class XI students of SMA Negeri 2 Tondano; (2) To describe the writing skills of the description text of the observation report of the XI grade students of SMA Negeri 2 Tondano by using a communicative approach. The method used is action research according to its type. The subjects of this study were students of grade XI in SMA Negeri 2 Tondano. The source of the data is 20 students and teachers. To collect data the techniques used are tests and observations. Acting in two rounds, the results showed that, in the implementation of the first round of Class XI Language Skills of SMA Negeri 2 Tondano in Writing Text Description of Observation Reports using the communicative approach was still in the range of percentage values of $66.20 \%$, categorized as less able. Based on the unsatisfactory results, the second round was carried out, and the results were in the successful category because they were in the able range of $84.40 \%$. These results indicate that the use of a communicative approach in learning to write descriptive text of the observation report has an impact or can improve the skills of 20 high school students of SMA Negeri 2 Tondano
\end{abstract}

Keywords: Writing skills; report text; observation results.

\section{Introduction}

One of the learning materials in the 2013 curriculum is writing a text report based on observations. Reporting Text Observation certainly requires the skills of a teacher to train students to observe or observe the surrounding environment and then pour it in one text and finally present it in class in the form of a report. When the researcher made observations at school, the researchers found that the students of class XI of SMA Negeri 2 Tondano generally did not understand how to observe an event let alone report it formally in front of the class. Learners still find it difficult to compile an observational text report. Mahsun (2014: 19) argues that one type of observation report is a descriptive report. Therefore, one type of observation text that is easier for students to do is descriptive observation text. That problem also becomes the problem of Indonesian language teachers in SMA Negeri 2 Tondano, as expressed by the teachers through conversation. The cause of the difficulties of 
students in carrying out observations in the school environment and reporting the text of the results of this descriptive observation is the incompatibility of methods with the learning approach used by the teacher. In learning the teacher does not consider the characteristics of the learning approach with the material and the characteristics of students. According to Kustiono (in Prasetyo 2004: 4). The teacher's habits in carrying out teaching and learning activities are still conventional and elementary, making teachers slow to think of more real learning alternatives. For example, by taking students outside the study room for practical learning purposes. In addition, teachers are less skilled at guiding students on how to prepare observational reports and then report verbally, while the needs of high school students are still very much dependent on the teacher's guidance in learning.

The communicative approach is used in language learning. The communicative approach arises because the phenomenon of language learning in the classroom is more about learning about structure or rules. The impact, students understand the rules of the use of language but are not proficient in using language in the context of real communication. This happens because language skills are a skill that must be trained. Communicative approach in language learning is an approach that emphasizes the mastery of the target language. In language learning with a communicative approach, students are trained to use language rules in real contexts (Larsen-Freeman, 2010: 123).

The text of the observation report includes four types namely, 1) description report, 2) clarification, 2) informative, and 4) scientific. So that this research is complete, the researcher only limits the type of description report, through a communicative approach. Furthermore, this study would like to answer the problems faced by students and teachers in learning Indonesian, namely, to describe the steps of learning a communicative approach in improving the writing skills of text description reports on the observations of class XI students of SMA Negeri 2 Tondano, as well as describing Research Benefit skills. .

It is hoped that this research can contribute to the development of more specialized knowledge in the field of Indonesian language learning, focusing on the skills of writing observational report text through communicative learning approaches. For students (students) can provide a pleasant learning experience so that students (students) are interested and can innovate in learning Indonesian. Teachers are expected to be able to develop learning by using various learning approaches that are suitable with the material. For schools to be contribute ideas in formulating communicative learning in accordance with the conditions of language use.

\section{Literature Review}

\section{a) Definition of Writing}

Writing is an activity to convey a message or communication using written language as a tool or medium, (Suparno and Yunus 2007: 1,3). Furthermore Tarigan (1983: 21) writes is to reduce or depict graphic symbols that describe a language understood by someone, so that other people can read the symbols of the graph if they understand the language and graphic images. 
Journal of Educational Method and Technology Vol. 2 No. 3, Desember 2019

P-ISSN 2622-8459 E-ISSN 2622-8467

http://ejournal.unima.ac.id/index.php/jemtec

\section{b) Understanding the Text}

The formulation of the concept of the text according to experts varies. According to Halliday in (Mahsun, 2014) the text is the path to understanding language. That is why texts are functional languages or languages that carry out certain tasks in the context of a situation. All examples of languages that take a certain part in the context of a situation are called texts. Thus, it can be stated the text is a statement of statement of a social activity that is verbal. Based on Halliday's formula, Mahsun (2014: 1) concludes that "text is a unit of language used as a means of social activity both verbally and in writing with a complete thought structure. From this formula, it can be understood that the understanding of the text includes two things, namely 1) oral text, and 2) written text. Spoken text is a language that is spoken or spoken to convey a message or information, while written text is a language written in the form of written symbols to convey a message or information.

\section{c) Text of Observation Report}

The text of the observation report is unique in terms of the content as well as the language used. The text of the observation report has the following content structure: 1) the title that gives rise to the characteristics of something to be informed, 2) the general classification contains an introduction to the phenomenon of the object to be discussed by including a general statement explaining the subject of the report, its description and classification, and 3) the description contains a description of phenomena / objects observed from section to section, habits or behavior for living things, or their use for objects. The text of the observation report also has the specificity of the language used. Judging from the language, the text of the observation report has the following characteristics: 1) usually uses nouns / nouns to inform something that is observed, 2) uses a state adjective to describe something / object being observed, and 3) uses action verbs to explain behavior, 4) using technical terms and 5) using concrete words according to facts.

d) Learning the Communicative Approach

The communicative approach is used in language learning. The communicative approach arises because the phenomenon of language learning in the classroom learns more about the structure and rules of any type of text. The impact, students understand the rules of the use of language but are not proficient in using language in the context of real communication. This happens because language skills are a skill that must be trained. Communicative approach in language learning is an approach that emphasizes the mastery of the target language. In language learning with a communicative approach, students are trained to use language rules in real contexts (Larsen-Freeman, 2010: 123).

Language is a communication tool. This is an assumption of a communicative approach. Learning languages means learning communication. Mastery of language in the context of real communication is the main target of language learning with a communicative approach. 
Journal of Educational Method and Technology Vol. 2 No. 3, Desember 2019

P-ISSN 2622-8459 E-ISSN 2622-8467

http://ejournal.unima.ac.id/index.php/jemtec

\section{Research Methods}

\section{Research Methods}

This research uses the action research method. Action research is the development of applied research or applied research, in this case researchers are like:

1) Active actor main activities

2) Change agent or agent of change

3) The subject or object under study gets the results of the actions given in a planned manner by the researcher, (Sukardi, 2016: 211).

Furthermore, Suparno, (2008: 8) states that action research research or action research is research conducted by someone who is practicing in a job to be used in the development of the work itself.

\section{Data Collection Technique}

1) Data Sources

The data sources are:

a. Students: to know the ability to write report texts on observations and active participation of students of class XI Language, SMA Negeri 2 Tondano in the classroom in learning.

b. Teacher: to find out the application of the communicative approach in learning to write observational report texts.

2) Data Collection Methods

1. Test, used to determine student learning outcomes. The test given consists of four aspects, in the form of essay test. The aspects assessed are:
a. report topic (Scoring 10)
b. report framework formulation (Scoring 30)
c. development of report content (Scoring 40)
d. make conclusions about the contents of the report (Scoring 20)

2. Observation, used to determine the implementation of learning through communicative approaches carried out by the teacher.

\section{Data analysis technique}

In analyzing test result data for each aspect, the formula used is:

$\mathrm{X}=$ Individual student grades

$\mathrm{A}=$ report topic (Scoring 10)

$\mathrm{B}=$ report framework formulation (Scoring 30)

$\mathrm{C}=$ development of report contents (Scoring 30)

$\mathrm{D}=$ draw conclusions from report content (Scoring30)

After individual grades are obtained, the researcher then looks for grade averages. The formula used is:

Information :

$=$ Grade point average

$=$ Number of $X$ values

$r=$ Number of students

\section{Strategic Plan (Renstra)}

The strategic plan (Renstra) for conducting this research is:

The first step 
Beginning with researchers conducting observations at school, compiling learning tools to write observational texts through communicative approaches in collaboration with Indonesian language study teachers at SMA Negeri 2 Tondano, compiling lesson plans, compiling teaching materials, preparing instructional media, determining implementation time, preparing observation sheets, determining time allocation and set assessment indicators.

Second step

The implementation of the action follows carefully controlled steps. The implementation follows the steps that have been included in the lesson plan. Collaborating with the teacher of Indonesian language studies, the action was carried out in two rounds. The researcher records and documents everything that happens in the class during the course of the action.

Third step

Researchers carefully observe all things that arise in Learning, including the way the teacher conducts actions and responses students throughout the learning carried out. At this stage implemented revision and improvement of weaknesses in the communicative approach learning observation skills in writing text.

Fourth Step

Reflection is done after analyzing the data and interpreting the data. This step is a means to review the actions taken on the research subjects that have been recorded in the observation.

Fifth Stage

Dissemination is held in the form of seminars with teachers in the field of Indonesian language studies by involving experts in a language learning approach that aims to improve and perfect Indonesian language teaching models and materials.

\section{Research Road Map}

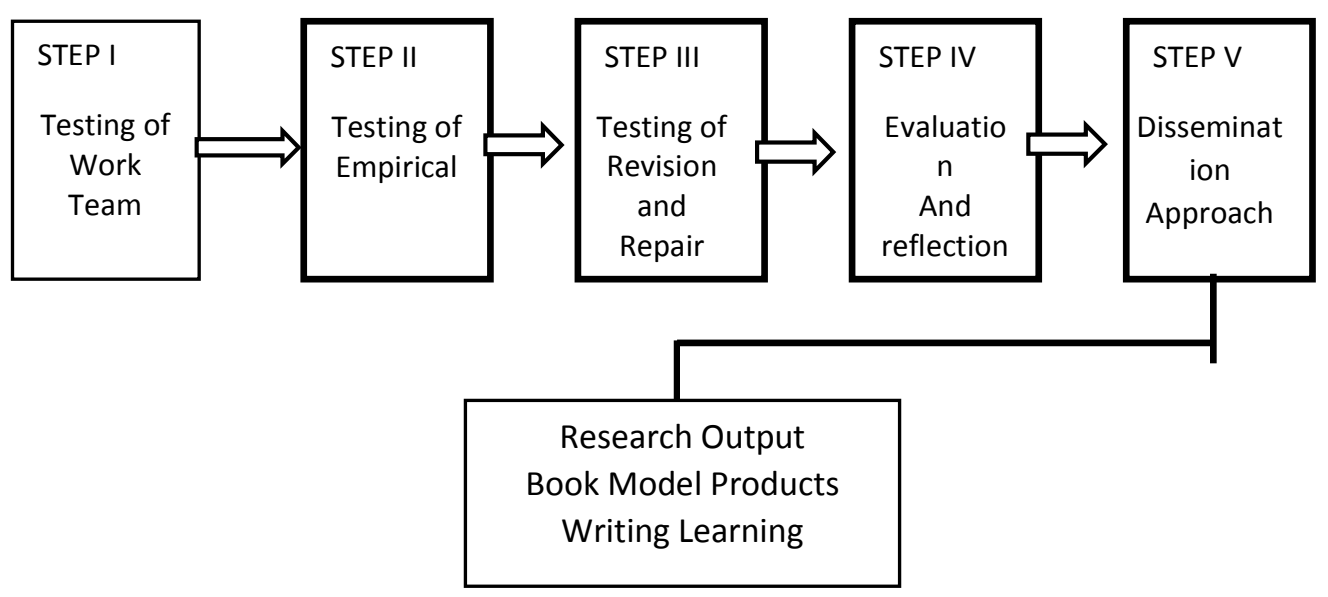


Journal of Educational Method and Technology Vol. 2 No. 3, Desember 2019

P-ISSN 2622-8459 E-ISSN 2622-8467

http://ejournal.unima.ac.id/index.php/jemtec

\section{Research Results and Discussion}

This stage begins with a description of the data that has been obtained or research findings that include a description of the skills of the XI grade students of SMA Negeri 2 Tondano in compiling the observation text through the application of communicative learning approaches. The study was conducted in 2 rounds.

a) Learning Description

Starting the data collection, the researcher conducted observations on the teacher who applied the communicative learning approach. Also observe the responses of the students of Class XI Language of SMA Negeri 2. 1. Application of the Communicative Learning Approach Learning the communicative approach includes the following steps: 4.1.1 Round I

1) Planning

(1) The researcher together with the school principal discusses everything related to the implementation of learning. The Principal informs the character and abilities of the XI grade in SMA Negeri 2 tondano so that the researchers carry out learning by involving all students' abilities. (2) Next the researcher held a discussion with the Home teacher about the condition of the students. Students with different behavior, habits and economics. Of course the treatment between students is also different. (3) Prepare RPP.

(4) After information from the school principal and Homeroom Teacher, the researcher compiles material about writing observational texts using a communicative learning approach.

(5) Arranging Student Worksheets (LKS).

(6) Then the researcher compiles a research instrument that includes observation sheets, tests, and interview guidelines.

(7) Prepare a package book.

(8) Prepare an assessment sheet and everything related to learning.

(9) Researchers prepare learning media in the form of charts containing material steps for writing observational report text.

2) Implementation

a. preliminary

1) The teacher greets, greets and checks student attendance.

2) The teacher provides motivation and conditions students to learn well.

3) The teacher gives an assignment to one of the students to lead prayer.

4) The teacher gives apperception.

5) The teacher gives motivation.

6) The teacher informs the learning objectives.

7) The teacher informs the steps of learning.

8) The teacher conditions students who are ready to learn.

b. Core activities

1) The teacher explains briefly about the concept of writing observational texts accompanied by examples.

2) The teacher explains the steps of writing observational text. 
3) The teacher distributes material about writing observational texts. Each student observes the sample text of the observation results and does the assignment in the worksheet.

4) The teacher assigns students to observe the conditions around the school for 15 minutes.

5) After finishing observing the nature around the school, the teacher asks students to write observational texts based on the results observed for 15 minutes.

6) The teacher guides students in the process of writing observational texts

7) After all students have done the assignment, writing the observation text, the teacher collects worksheets that are consistent with writing the observation report text.

8) The teacher explains again how to write the text of the observation results in accordance with the steps of learning the communicative approach, finally the teacher and students conclude the assignments that have been produced by students.

\section{c. Closing}

1) To evaluate students' ability to write observational texts, the teacher gives several questions verbally.

2) Together with students, the teacher discusses and informs the results achieved by students, as well as giving emphasis to problems that have not yet been achieved.

3) The teacher gives additional tasks as a follow-up to the discussion of writing observational text material to achieve completeness.

b) Observation Results

At the time of learning carried out by Indonesian language teachers, using a communicative approach in learning to write observational texts, the observations such as data can be seen through the following table: 
Journal of Educational Method and Technology Vol. 2 No. 3, Desember 2019

P-ISSN 2622-8459 E-ISSN 2622-8467

http://ejournal.unima.ac.id/index.php/jemtec

Table 1. Observation Results

\begin{tabular}{|c|c|c|c|c|c|c|c|}
\hline \multirow{2}{*}{ Student } & \multicolumn{3}{|c|}{ Respond } & \multicolumn{3}{c|}{ Responsibility } & \multirow{2}{*}{ Notes } \\
\hline & Good & Adequate & Less & Good & Adequate & Less & \\
\hline $\mathbf{0 1}$ & & $\sqrt{ }$ & & $\sqrt{ }$ & & & \\
\hline $\mathbf{0 2}$ & $\sqrt{ }$ & & & & $\sqrt{ }$ & & \\
\hline $\mathbf{0 3}$ & $\sqrt{ }$ & & & $\sqrt{ }$ & & & \\
\hline $\mathbf{0 5}$ & & & $\sqrt{ }$ & $\sqrt{ }$ & & & \\
\hline $\mathbf{0 6}$ & $\sqrt{ }$ & & & & & & \\
\hline $\mathbf{0 7}$ & & $\sqrt{ }$ & & $\sqrt{ }$ & & & \\
\hline $\mathbf{0 8}$ & $\sqrt{ }$ & & & & $\sqrt{ }$ & & \\
\hline $\mathbf{0 9}$ & & $\sqrt{ }$ & & & & $\sqrt{ }$ & \\
\hline $\mathbf{1 0}$ & $\sqrt{ }$ & & & $\sqrt{ }$ & & & \\
\hline $\mathbf{1 1}$ & $\sqrt{ }$ & & & & $\sqrt{ }$ & & \\
\hline $\mathbf{1 2}$ & & & $\sqrt{ }$ & & $\sqrt{ }$ & & \\
\hline $\mathbf{1 3}$ & & $\sqrt{ }$ & & $\sqrt{ }$ & & & \\
\hline $\mathbf{1 4}$ & $\sqrt{ }$ & & & $\sqrt{ }$ & & & \\
\hline $\mathbf{1 5}$ & $\sqrt{ }$ & & & & & $\sqrt{ }$ & \\
\hline $\mathbf{1 6}$ & $\sqrt{ }$ & & & & $\sqrt{ }$ & & \\
\hline $\mathbf{1 7}$ & $\sqrt{ }$ & & & $\sqrt{ }$ & & & \\
\hline $\mathbf{1 8}$ & & $\sqrt{ }$ & & & & $\sqrt{ }$ & \\
\hline $\mathbf{1 9}$ & & $\sqrt{ }$ & & $\sqrt{ }$ & & \\
\hline $\mathbf{2 0}$ & $\sqrt{ }$ & & & & $\sqrt{ }$ & \\
\hline & & & & & & \\
\hline
\end{tabular}

The results of observations on the application of communicative approaches in learning to write texts of observations carried out by 20 students of SMA Negeri 2 Tondano. Twenty students were observed and students have responded to good learning as many as 12 people more than $50 \%$, six students were enough and two students were less. Based on the aspect of responsibility, it is seen that students in the category are 'good' and others are classified as 'good enough' and 'not good'. The response shown by all students asked about the material and assignments they did not understand, other students answered questions if they understood it.

These students' responses and responsibilities have an impact on learning activities that are focused on students (active students). 
b) Data Description of First Round Test Results

Data on the implementation of communicative approaches in learning to write observational texts can be seen in the following table

Table 2. First Round Test Results

\begin{tabular}{|c|c|c|c|c|c|}
\hline Student & $\begin{array}{c}\text { Topic } \\
\text { (10) }\end{array}$ & $\begin{array}{c}\text { Report } \\
\text { template } \\
(30)\end{array}$ & $\begin{array}{c}\text { Report } \\
\text { Development } \\
(30)\end{array}$ & $\begin{array}{c}\text { Conclusion } \\
\text { (30) }\end{array}$ & $\begin{array}{c}\text { Total } \\
\text { of } \\
\text { Score }\end{array}$ \\
\hline S1 & 7 & 15 & 15 & 13 & 50 \\
\hline S2 & 8 & 20 & 20 & 22 & 70 \\
\hline S3 & 9 & 15 & 21 & 25 & 70 \\
\hline S4 & 6 & 20 & 20 & 19 & 65 \\
\hline S5 & 9 & 25 & 23 & 16 & 73 \\
\hline S6 & 8 & 26 & 21 & 25 & 80 \\
\hline S7 & 5 & 10 & 15 & 16 & 46 \\
\hline S8 & 7 & 24 & 18 & 16 & 65 \\
\hline S9 & 8 & 23 & 24 & 20 & 75 \\
\hline S10 & 6 & 15 & 16 & 20 & 52 \\
\hline S11 & 8 & 27 & 14 & 22 & 71 \\
\hline S12 & 10 & 27 & 22 & 21 & 80 \\
\hline S13 & 7 & 25 & 20 & 18 & 70 \\
\hline S14 & 9 & 26 & 22 & 25 & 82 \\
\hline S15 & 8 & 25 & 23 & 19 & 75 \\
\hline S16 & 7 & 20 & 16 & 17 & 60 \\
\hline S17 & 9 & 26 & 21 & 19 & 75 \\
\hline S18 & 5 & 15 & 17 & 13 & 50 \\
\hline S19 & 6 & 16 & 14 & 14 & 55 \\
\hline S20 & 7 & 20 & 19 & 14 & 60 \\
\hline Total & 155 & 420 & 381 & 392 & 1324 \\
\hline
\end{tabular}

Based on the data in table 2 shows clearly that the ability of students to write the text of the observation report is still in the category of quite capable because the acquisition of the average value of the class is $66.20 \%$. It can also be concluded that the use of communicative approaches in learning to write observational texts has not been maximized. The data shows that it is necessary to carry out the second round to maximize the ability of the eleventh grade students of SMA Negeri 2 Tondano.

e) Round I

1) Planning

1. The researcher conducts an evaluation with the homeroom teacher regarding student achievement in the first round. .

2. Arrange lesson plans with the same topic or material, namely the skills of writing observational text through a communicative approach. 
3. Arranging Student Worksheets (LKS).

4. Develop research instruments that include observation sheets, tests, and interview guidelines.

5. Prepare teaching material books.

6. Prepare an assessment sheet and everything related to learning.

7. Researchers prepare learning media in the form of charts containing material steps for writing observational report text.

\section{Implementation}

a. Preliminary

1) The teacher greets, greets and checks student attendance.

2) The teacher provides motivation and conditions students to learn well.

3) The teacher gives an assignment to one of the students to lead prayer.

4) The teacher gives apperception.

5) The teacher gives motivation.

6) The teacher informs the learning objectives.

7) The teacher informs the steps of learning.

8) The teacher conditions students to be ready to learn.

b. Core activities

1) The teacher explains briefly about the concept of writing observational texts accompanied by examples.

2) The teacher explains the steps of writing observational text through a communicative approach.

3) The teacher distributes material about writing observational texts. Each student observes the sample text of the observation results and does the assignment in the worksheet.

4) The teacher assigns students to observe the conditions around the school for 15 minutes.

5) After finishing observing the nature around the school, the teacher asks students to write observational texts based on the results observed for 40 minutes.

6) The teacher guides students in the process of writing observational texts

7) After all students have done the assignment, writing the observation text, the teacher collects worksheets that are consistent with writing the observation report text.

8) The teacher explains again how to write the text of the observation results in accordance with the steps of learning the communicative approach, finally the teacher and students conclude the task that has been written by the student.

c. Closing

1) To evaluate students' ability to write observational texts, the teacher gives several questions verbally.

2) Together with students, the teacher discusses and informs the results achieved by students, as well as giving emphasis to problems that are not yet understood by students. 
Journal of Educational Method and Technology Vol. 2 No. 3, Desember 2019

P-ISSN 2622-8459 E-ISSN 2622-8467

http://ejournal.unima.ac.id/index.php/jemtec

3) The teacher gives additional tasks as a follow-up to the discussion of writing observational text material to achieve completeness.

Description of Data on Second Round Test Results

Data on the implementation of communicative approaches in learning to write observational texts can be seen in the following table:

Table 3. Second Round Test Results

\begin{tabular}{|c|c|c|c|c|c|}
\hline Student & $\begin{array}{c}\text { Topic } \\
\text { (10) }\end{array}$ & $\begin{array}{c}\text { Report } \\
\text { Template } \\
\text { (30) }\end{array}$ & $\begin{array}{c}\text { Report } \\
\text { Development } \\
\text { (30) }\end{array}$ & $\begin{array}{c}\text { Conclusion } \\
\text { (30) }\end{array}$ & $\begin{array}{c}\text { Total } \\
\text { of } \\
\text { Score }\end{array}$ \\
\hline S1 & 9 & 28 & 26 & 27 & 90 \\
\hline S2 & 8 & 26 & 23 & 28 & 85 \\
\hline S3 & 7 & 27 & 25 & 26 & 85 \\
\hline S4 & 9 & 28 & 27 & 26 & 90 \\
\hline S5 & 8 & 26 & 25 & 21 & 80 \\
\hline S6 & 7 & 25 & 27 & 16 & 75 \\
\hline S7 & 8 & 27 & 26 & 24 & 85 \\
\hline S8 & 9 & 28 & 27 & 26 & 90 \\
\hline S9 & 8 & 26 & 25 & 20 & 79 \\
\hline S10 & 8 & 28 & 27 & 25 & 88 \\
\hline S11 & 7 & 25 & 24 & 14 & 70 \\
\hline S12 & 8 & 27 & 26 & 26 & 87 \\
\hline S13 & 7 & 26 & 25 & 20 & 78 \\
\hline S14 & 9 & 28 & 27 & 26 & 90 \\
\hline S15 & 8 & 24 & 26 & 27 & 85 \\
\hline S16 & 9 & 27 & 26 & 28 & 90 \\
\hline S17 & 8 & 28 & 25 & 26 & 87 \\
\hline S18 & 8 & 27 & 28 & 25 & 88 \\
\hline S19 & 7 & 25 & 24 & 20 & 76 \\
\hline S20 & 9 & 28 & 28 & 25 & 90 \\
\hline Jumlah & 153 & 526 & 517 & 476 & 1688 \\
\hline
\end{tabular}

Based on the data in table three, it turns out that the students' ability to write observational report texts has increased in the able category because the average grade acquisition is $84.40 \%$. It can be concluded that the use of a communicative approach in learning to write observational texts plays an important role in learning and students learn to the fullest. 
Journal of Educational Method and Technology Vol. 2 No. 3, Desember 2019

P-ISSN 2622-8459 E-ISSN 2622-8467

http://ejournal.unima.ac.id/index.php/jemtec

\section{Discussion}

Data in the first and second rounds show that there was a significant increase. In the first round it was clearly seen that: 1) Topic aspects of the report students got the following results: two students got a weight of 5, three students got a weight of 6 , 5 students got a weight of 7, 5 students got a weight of 8,4 students got a weight of 9 and 1 students get a weight of 10.2) Aspects of the Report Framework Formulation, 1 student gets a weight of 10, 4 students get a weight of 15,1 student gets a weight of 16,4 students get a weight of 20, 1 student receives a weight of 23,1 student receives a weight of 24, 3 students gaining weight 25, 3 students gaining weight 26 and 2 students gaining weight 27. 3) Aspects of developing Report Content, 2 students gaining weight 14, 3 students gaining weight 15, 2 students gaining weight 16,1 student gaining weight 17,1 student gaining weight weight 18,1 student gained weight 19, 3 students gained weight 20, 2 students gained weight 21, two students gained weight 22, 2 students gained weight 23, and 1 student gained weight 24. 4) Aspect of Making Conclusions Report Content, 2 students obtain weight 13, 4 students gained a weight of 14, 3 students gained a weight of 16, 1 student gained a weight of 17,1 student gained a weight of 18 , two students gained a weight of 19 , and 2 students gained a weight of 22 .

In the second round there was an increase in the achievements of all students with their respective grades, 1) Report Topic Aspects 5 students gained a weight of 7, 9 people gained a weight of 8, and 5 students gained a weight of 9. 2) Aspects of the Report Framework Formation 1 students obtained weight 24, 3 students get weight 25, 4 students get weight 26, 5 students get weight 27 and 7 students get weight 28. 3) Aspect of Report Content Development, 1 student gets weight 23, 2 students get weight 2, 5 students get weight 25,5 students got a weight of 26, 5 students got a weight of 27, and 2 students got a weight of 28. 4) Aspect of Making Conclusions Report Content, 1 student gained a weight of 14, 1 student gained a weight of 16, 3 students gained a weight of 20, 1 student gained weight 24, 3 students get weight 25, 6 students get weight 26, 3 students get weight 27 and 2 students get weight 28 .

The results of the XI grade students' achievement in Tondano High School 2 in writing the description text of the observation report using the communicative method in the second round were in the range of $84,40 \%$ categorized as capable. With the results in the able category, the use of communicative learning methods is very instrumental in arousing the learning enthusiasm of high school students and their equivalents. Although the learning process requires the teacher's creativity in using this method, so students can be motivated to respond and involve themselves during the learning process.

All Indonesian language lessons start from elementary school (SD) to text based high school (SMA), (Mahsun, 2014: 189). That opinion was in accordance with text-based 2013 curriculum requirements.

\section{Closing \\ Conclusion}

Learning writing the text of the Observation Report Report using the communicative method through the following steps: (1) The teacher gives apperception, (2) The teacher gives motivation. (3) The teacher informs the learning 
Journal of Educational Method and Technology Vol. 2 No. 3, Desember 2019

P-ISSN 2622-8459 E-ISSN 2622-8467

http://ejournal.unima.ac.id/index.php/jemtec

objectives, (4) The teacher conditions students who are ready to learn. Next to the core activities (5) The teacher explains briefly about the concept of writing observational text. (6) The teacher explains the steps of writing observational text. (7) The teacher distributes material about writing observational text. Each student observes an example of the text results of observations and work on assignments in the worksheet. (8) The teacher assigns students to observe conditions around the school. (9) After finishing observing the nature around the school, the teacher assigns students to write the observation text. (10) The teacher guides students in the process of writing observational texts. (11) The teacher gives additional tasks as a follow-up to the discussion of writing observational text material to achieve completeness. B. Class XI Language Skills of SMA Negeri 2 Tondano in Writing Text Description of Observation Reports using the communicative approach is considered successful because it is in the range of able with a percentage of $84.40 \%$. This learning is carried out in 2 (two) rounds. The first round of student achievement is in the category of underprivileged with a percentage of $66.20 \%$.

\section{Suggestion}

Learning the communicative approach is highly recommended for use in learning Indonesian, of course, with material that is appropriate with this approach. Students' learning motivation is built up with learning of communicative approaches so that the results are in the able category.

Creative teachers will try to condition learning based on students, so that positive responses from students will create enjoyable learning. The students are directed towards optimal self-development and ability, and in accordance with the objectives, in the end the class XI students of SMA Negeri 2 Tondano are able to write a description text of the observation report even in a short time.

\section{REFERENCES}

Atar Semi, 2007. Dasar-Dasar Keterampilan Menulis. Bandung: Angkasa.

Azies, Furganul dan A. Chaedar Alwasilah. 1996. Pengajaran Bahasa Komunikatif: Teori dan Praktek. Bandung. Remadja Rosda Karya.

Dhieni, dkk. 2008. Metode Pengembangan Bahasa. Universitas Terbuka.

Kurikulum 2013. Kementerian Pendidikan dan Kebudayaan.

Mahsun, 2014. Teks dalam Pembelajaran Bahasa Indonesia. Jakarta: PT. Grafindo Perkasa

Nafiah, H, 1981. Anda Ingin Jadi Pengarang. Jakarta : Usaha Nasional.

Nurjamal, dkk. 2011. Keterampilan Berbahasa. Jakarta: Gramedia.

Loelock Endah Poerwati, dkk. 2013. Kurikulum 2013. Jakarta : Prestasi Pustakaraya.

Sapani, Suardi, dkk. 1998. Teori Pembelajaran Bahasa. Depdikbud.

Soeparno, 2009. Menulis. Jakarta : Universitas Terbuka.

Sugiyono, 2009. Metode Penelitian Pendidikan (Pendekatan Kuantitatif, Kualitatif dan R \& D) Bandung: Alfabeta).

Suriamiharja, A, dkk. 1996/1997. Petunjuk Praktis Menulis. Jakarta : Departemen P dan K Dirjen PDM.

Tarigan, 1983. Menulis Sebagai Suatu Keterampilan. Bandung : Angkasa Raya. 
Journal of Educational Method and Technology Vol. 2 No. 3, Desember 2019

P-ISSN 2622-8459 E-ISSN 2622-8467

http://ejournal.unima.ac.id/index.php/jemtec

Trianto, 2007. Model-model Pembelajaran Inovatif Berorientasi Konstruktivistik. Jakarta : Prestasi Pustaka.

Widodo, HS. 1987. Piranti Kohesi Sebagai Unsur Teks dalam Nurhadi (ed.). Kapita Selekta Kajian Bahasa, Sastra, dan Pengajarannya. FPBS IKIP : Malang. Zaini, H, dkk. 2002. Strategi Pembelajaran. KTSP. 